\title{
Den etterlevande familien
}

Ved Agnar Meling

Når eit menneske har teke sitt liv, vil det (som oftast) vere ein familie som set att med saknet, spørsmåla og eit virvar av kjensler. Korleis ein familie går gjennom sorga etter eit slikt dramatisk dødsfall, vil variere frå familie til familie. Det kan vere nyttig å sjå dei etterlevande i eit familienivå, og eg vil i denne artikkelen kome med nokre tankar vi har gjort oss ved Familievernkontoret i Sør-Trøndelag. I tillegg byggjer eg på mi houudoppgåve i sosialt arbeid (Meling 1992).

\section{Kven høyrer til familien?}

Når vi snakkar om den etterlevande familie, er det vanleg å tenkje på den nære familie. Då meiner vi oftast dei som budde saman med den døde og dei som har eit nært slektskap (foreldre, barn, søsken) med den døde. Dei mange og nye familiebilete som teiknar seg i dag, gjer at det likevel ikkje er klart kven som reknar seg som etterlevande til ein som har teke sitt liv. Ut frå mi erfaring hender det ofte at vi helse- og sosialarbeidarar overser mange etterlevande. I tillegg til slektningar kan og naboar, arbeidskollegaer og klassekameratar vere etterlevande og kan ha trong for å ha nokon å snakke med.

\section{Kva er spesielt med den etterlevande familie?}

Journalisten og forskaren Alison Wertheimer, som sjølv var etterlevande, intervjua mange etterlevande familiar etter sjølvmord. Ho seier at det einaste dei deler med kvarandre er det faktum at dei er etterlevande etter sjølvmord. Men det var også det som ofte fekk dei til å kjenne seg annleis enn andre familiar dei kjende (Wertheimer 1991). Eg trur det er viktig at vi alltid er opne for det unike hos desse familiane. Alle familiar har si soge, sin kultur og sine mønster dei handlar etter. Ei viktig hjelp kan vere å få dei til å finne fram og reflektere over nettopp dette. Mange familiar opplever at sjølvmordet har gjeve dei eit stempel, og at familien er påført skam. Dette gjeld ikkje for alle. I blant har vi opplevd at familiemedlemmer opplever at dei som familie blir sett opp til av folk i omgjevnaden fordi dei har hatt så mykje liding. Det kan vere at lidinga og det å koma gjennom den, gjer at dei også opplever seg som verdige og stolte.

\section{Familien sine utfordringar etter eit sjølvmord}

Tida like etter eit sjølvmord er ei vanskeleg tid for familien. Dei sterke reak- sjonane som blir vekt hos medlemmene, gjer at dei er lite i stand til å gjere val sjølve. Når familien samlar seg som ein til vanleg gjer etter eit d $\varnothing \mathrm{d}$ sfall, for å s $\varnothing$ kje tr $\varnothing$ st og st $\varnothing$ tte og for å dele sine opplevingar, er dette ofte ein vanskelegare prosess når d $\varnothing$ dsfallet er sjølvmord. Den heilande prosessen som ei samling kan vere, kan altså bli forstyrra ved dramatiske dødsfall. Ulike oppfatningar om kvifor han/ho tok livet sitt, konflikter før sjølvmordet mellom familiemedlemmer og andre historier i familien, kan gjere at det som kunne vore st $\varnothing$ tte i staden blir opplevingar som vanskeleggjer sorga i tida som følgjer etter. Bl.a. har vi sett at familiane har tendens til å oppfatte slektningane (og personar frå hjelpeapparatet) som anten "kvite" eller "svarte". Dei som er "svarte", vil ein ikkje ha hjelp i frå. I staden for å ta i mot hjelp, bruker ein krefter på å halde dei (svarte) på avstand. Dette kan igjen verke inn på korleis familien utviklar seg.

\section{Ein familie endrar seg ved eit dødsfall}

Når det er sjølvmord som er årsaka til d $\varnothing$ dsfallet, trur eg endringane er st $\varnothing$ rre fordi sjølvmordet rører så sterkt ved relasjonane. Familien treng å finne ein ny organisering samstundes som den skal gå gjennom ei normal utvikling. Jordan, Kraus og Ware (1993) peikar på at eit dramatisk dødsfall kan vanskeleggjere den normale familieutviklinga. Anten kan familien låse seg og bli ein isolert familie som har nok med seg sjølv, eller bli ein familie der familiemedlemmer bryr seg lite om kvarandre. I den isolerte familie har dei funne redsle, frykt og depresjon som den dominerande affekttonen. Medlemmene er overvaktsame på signal om liding og smerte hos dei andre, og dette fører til at dei unngår vanskelege emne, ikkje minst sorgreaksjonar etter den døde. Barna kan bli parentifiserte (ta på seg foreldreroller) og meir avhengige og umodne enn det ein ventar ut frå alder, og dei får vanskar med å flytta frå heimen. I "greie seg aleine"-familien finn dei sinne og skuldkjensle. Familiemedlemmene fokuserer på seg sjølv og søkjer st $\varnothing$ tte og trøst hos jamaldrande utanfor familien eller søkjer terapi. Familien blir heller "gal" enn trist, og det skapar konfliktar, syndebukkar og fiendskap. Hos ungdommane vil ein kunne finne utoverretta reaksjonar, inklusiv vold og vanskar med autoritetar og seksuell utpr $\varnothing$ ving.

\section{Barn og familien}

Barna kan lett bli "usynlege" når det skjer eit sjølvmord i ein familie. Dei vaksne har nok med sin smerte og fortviling og ser ikkje barna, og barna får ikkje kontakt med dei vaksne. Barna kan få uklare svar på kva som har hendt, og då kan dei lage seg historier og fantasier om den d $\varnothing$ de og korleis han/ho d $\varnothing$ de. Dei kan ta på seg skulda for sjølvmordet, t.d. kan dei tenkje at deira framferd fekk mor eller far til å ta livet sitt.

Barn kan få eller ta på seg nye roller i familien etter eit sjølvmord. Vår erfaring er at alder og kjønn spelar inn i kva for roller dei får: Den eldste jenta tok på seg omsorgsoppgåva for yngre søsken. Oppgåva kunne variere frå å sørgje for at dei alltid visste kor søskena var, til å stikke innom (når dei hadde flytta ut) for å høyre korleis dei andre hadde det. Denne omsorgen opplevde dei batt dei til å vere heime eller bu i nærleiken. Yngre søsken merka at dei blei passa på og var ikkje glade for den merksemda. Dei yngre på si side opplevde at dei skulle erstatte den døde søster eller bror, - på ein måte skulle dei gå i den andre sine fotspor. Ofte har vi opplevd at det døde søsken blei skildra som svært positiv med berre gode eigenskapar. Det var vanskeleg å leve opp til dei forventningane som dei opplevde låg i å følgje etter det døde søsken. Når dei nærma seg den alderen då broren/ søstera tok livet sitt, blei dei passa ekstra godt på. Er det ein av foreldra som har teke livet sitt, ser vi ofte at den eldste av same kjønn 


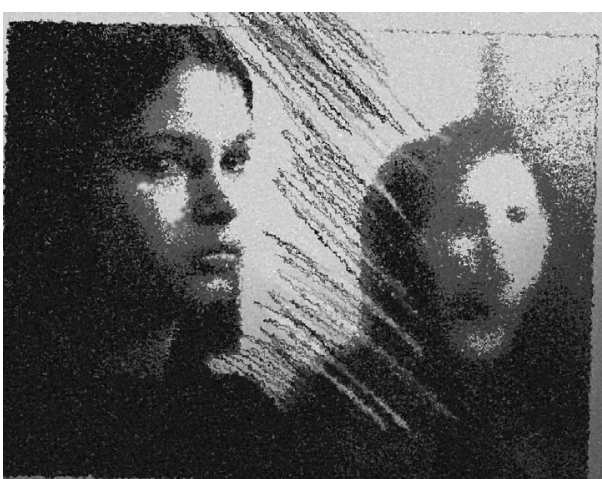

tek på seg dei oppgåvene den døde hadde. Ofte er det for store oppgåver, og ein kjenner seg mislukka trass i stor innsats.

Er det konfliktar i familien, t.d. på grunn av at familien til far gjev mor skulda for at far tok livet sitt, kjem barna i ein lojalitetskonflikt mellom mor og far si slekt. Dei blir på ei side bodbringarar over konfliktgrensene samstundes som dei ikkje skal røpe det som skjer på andre sida.

\section{Kva kan vi gjere?}

Sidan vi arbeider ved eit familievernkontor, er det ikkje vi som får vite om sjølvmord først. Det vil vere personar frå det lokale hjelpeapparatet (lege, prest, kriseteam og liknande) som er dei første hjelparane, og som må ha kompetanse til å m $\varnothing$ te familien i den første tida etter sjølvmordet. Den tidlege hjelpa er svært viktig, og familiane bind seg ofte til dei som dei får hjelp hos i den tida. I høve til einskilde kommunar er vi for tida klar til å kunne møte familien raskt etter sjølvmordet, og gjerne saman med nokre av dei lokale hjelparane, men av både praktiske og $\varnothing$ konomiske grunnar har det vore vanskeleg å gje eit slikt tilbod til alle kommunane i fylket. Vi har registrert at fleire familiar $\varnothing$ nskjer å snakke med nokon som ikkje høyrer til i det lokale apparatet. Vi lurer på om det kan ha samanheng med at det ikkje er alle "løyndommar" dei vil bli minna på når dei treff hjelpearbeidarane på butikken, bensinstasjonen, festar og musikkarrangement eller om det har med skamkjensla å gjere.

\section{Skal barn vere med i samtalen?}

Vi oppmodar familien til å ha med barna. Om dei vel å ikkje ha med barna, tek vi opp temaet og får dei til å ta ei avgjer om kven som skal fortelje barna om det som har hendt, om det ikkje er gjort. Det er viktig at det er personar dei har tillit til og er trygge på. Dersom dei vaksne, t.d. foreldra, er utrygge på korleis dei skal fortelje barna om det som har hendt, lagar vi avtale om at vi eller andre kan hjelpe dei med det. Når barna er med, ser vi på dei som ein ressurs. Sidan sjølvmord ofte skapar skam i familien, vil barna kunne vere med på å vise fram det familien kan vere stolt over. Barn har og evne til å snakke direkte og kan ta fram tema som dei vaksne går unna.

Det er viktig at barna får klare og enkle skildringar av det som har hendt. Vi må vere merksame på at barn vil fange opp korleis dei vaksne reagerer, og at dei kan ta på seg andre sine sorger og smerter i tillegg til eiga sorg. I samtalegrupper med barn har det vist seg at det å dele felles opplevingar ikkje var til nytte for dei. Dei tok berre inn over seg andre sine opplevingar i tillegg. Å teikne, male eller leike ut si smerte kan vere til nytte for yngre barn.

\section{Vårt første møte med familien}

På dette møtet er vi opptekne av å få tak i det som har hendt. Vi kan seie at vi har ein slags utforskarhaldning. Vi treng å få vite om hendinga for å kunne skjøne familien sin situasjon og vi trur at familiemedlemmene har nytte av å gå detaljert igjennom det som hendte. Det blir og starten på eit individueringsarbeid. Det er viktig at alle får kome med sine opplevingar og si skildring av det som hendte, og korleis dei fekk vite om det og kva dei gjorde. Vi er særleg merksame på det som blei opplevd ulikt og markerer det når det kjem fram. Det er viktig at dei gjev kvarandre anerkjenning og stadfesting på det som er ulikt. Oppfatningar om den d $\varnothing$ de og dei ulike relasjonane dei hadde til den døde, prøver vi og å få fram.

\section{Etter som tida går}

Å sørgje er ingen sjukdom. Mange familiar har ressursar og tek i bruk støtte frå slekt, naboar og vener, slik at dei kjem seg igjennom sorga. Likevel er det og mange som seier at dei skulle hatt hjelp dei første åra etter sjølvmordet. Alt snakk i media om krisepsykiatarar har verka sårande for mange.

Vi opplever det nyttig å avtale kontakt med familiane i minst eit år. Det ser det ut til at familiane også gjer. Opplevingane kan svinge mykje dei første åra. Ei veke kan vere mørk og tung, medan neste kan vekkje til live glød og optimisme. Vi lar familien for det meste avgjere kor ofte vi skal møte dei. Det vi ser som vårt bidrag er å halde oppe samtalen om den døde og om korleis dei tek vare på kvarandre, korleis dei vil bli teken vare på og om andre ser det dei treng. Saman teiknar vi eit nettverkskart der dei får sjå kven som støttar dei og som dei kan få hjelp hos. I blant dei kan det vere andre som har same oppleving som dei, og som det kan vere godt å dele erfaringane med. Soger og forteljingar frå fortida, bl.a. om den døde, prøver vi å få fram og gjennom forteljingane hente fram ressursane $i$ familien. Desse ressursane kan dei ta med seg vidare i livet. Vårt mål er å få familien til å reflektere over det som har hendt og korleis dei ser for seg framtida, slik at dei igjen kan ta tak i sine liv og sine skapande krefter.

\section{Sitert litteratur}

Jordan, John R, Kraus, David R, Ware, Eugenia S. Observations on loss and family development. Family process 1993: 425-40

Meling, Agnar. Dei tapte relasjonane:

barn etter fars sjølvmord.

Dragvoll : Universitetet i Trondheim, Institutt for sosialt arbeid, [1992]. Hovudoppgåve i sosialt arbeid

Wertheimer, A. A special scar.

London: Routledge, 1991

\section{Annen aktuell litteratur}

Dyregrov, Atle. Katastrofepsykologi. Oslo: Ad Notam/Gyldendal, 1993

Dyregrov, Atle. Sorg hos barn: en håndbok for voksne. Bergen: Sigma, 1989

Irgens, Eva / Meling, Agnar: Rapport fra sorggrupper for etterlatte etter selvmord. Trondheim: Familievernkontoret i Sør-Trøndelag, 1992.

Irgens, Eva / Meling, Agnar: Rapport fra sorggrupper for s $\phi$ sken etter selvmord. Trondheim: Familievernkontoret i S $\varnothing$ r-Trøndelag, 1993.

Mehlum, Lars. Etter selvmordet.

I Mehlum, Lars (red): Tilbake til livet:

selvmordsforebygging i teori og praksis.

Kristiansand: Høyskoleforlaget, 1999: 218-32

Ronge, Kari. Vi som blir igjen: mennesker i m $\phi$ te med sorgen - og livet som går videre.

Oslo: Grøndahl Dreyer, 1998

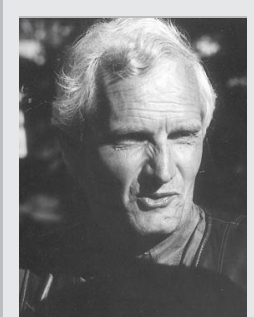

Agnar Meling har arbeidd som familieterapeut ved Familievernkontoret i $\varnothing \varnothing$ Trøndelag sidan 1980. Han er cand. socion og utdannet sosionom og sykepleier. I 1992 tok han embetseksamen i sosialt arbeid med hovudoppgåve (Dei tapte relasjonane) om barn etter at far hadde teke livet sitt. 